Reprod. Nutr. Dévelop. 1980, 20 (4 A), 975-982.

\title{
Quantitative studies on spermatogenesis in buffalo (Bubalus bubalis)
}

\author{
par G. S. BILASPURI, S. S. GURAYA
}

Department of Zoology, Punjab Agricultural University Ludhiona-141004, Punjab, India.

Summary. The qualitative behaviour of spermatogenetic cells and Sertoli cells in the buffalo (Bubalus bubalis) was studied by identifying 8 stages of the seminiferous epithelium cycle based on meiotic division and morphology as well as the position of more mature spermatids. To achieve better results, stages 1, 2, 3, 4 and 8 were sub-divided. Six peaks of spermatogonial mitosis suggested six generations of spermatogonia. Of these, three were ve to $A\left(A_{1}, A_{2}, A_{3}\right)$, two to $B\left(B_{1}, B_{2}\right)$ and one to intermediate spermatogonia. However,

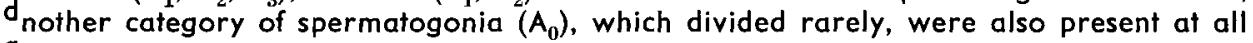
a ages of the cycle. $A_{1}, A_{3}, I_{n^{-}}, B_{1}$-spermatogonia and secondary spermatocytes showed 20 , sł8.75, 10.2, 15.5 and 10 p. 100 degeneratian, respectively, No degeration was observed $1 \mathrm{n} A_{2}$ and $B_{2}$-spermatogonia, primary spermatocytes or spermatids. The degeneration iof these various spermatogenetic cells greatly affected the efficiency of spermatogenesis.

\section{Introduction.}

Some work has already been done on the spermatogenetic cells and the seminiferous epithelium cycle of the buffalo (Guraya and Bilaspuri, 1976a, b, c). The quantitative aspects of spermatogenesis have been investigated in some mammals (Oakberg, 1955 ; Amann, 1962 ; Courot, 1962 ; Attal and Courot, 1963 ; Desclin and Ortavant, 1963 ; Hochereau de Reviers, 1970 ; Clermont, $1972 a$; Berndtson and Desjardins, 1974), but these criteria have not yet been investigated in the buffalo. The present study undertakes to determine the behaviour of various spermatogenetic cells and Sertoli cells during different stages of the seminiferous epithelium cycle (SEC). Such studies show the efficiency of spermatogenesis and form the basis for assessing the effects of various drugs, chemicals, hormones and climatic factors on spermatogenesis and sperm production in buffalo.

\section{Material and methods.}

Testicular material was taken from 6 sexually mature buffalo bulls (Bubalus bubalis) during the spring by excision of the whole testis or by biopsy of both testes. To excise the testis, $500 \mathrm{mg}$ of chlorpromazine hydrochloride (Largactil) was adminis- 
trated to the buffaloes $45 \mathrm{~min}$ prior to surgery. The scrotum was scrubbed thoroughly and 2 p. 100 procaine hydrochloride was infiltered on its lateral border. A 7.5 to $10 \mathrm{~cm}$ incision was made through the dartos, sub-dartos and tunica vaginalis. The testicle was removed from the scrotum, the blood vessels ligated and transfixed, and the skin closed with Halsted sutures using No. 2 silk. The animals were given antibiotics for 5 days after the operation, and the sutures were removed on the 7th day. For biopsy, a 2.5 to $5 \mathrm{~cm}$ incision was made and a small triangular piece of testis was removed using a No. 12 BP blade.

After the operation, the testicular material was immediately cut into small pieces in physiological saline (0.9 p. 100) and then fixed in Zenker formol. After the usual dehydration, the material was embedded in paraffin wax. The sections were cut at $5 \mu \mathrm{m}$ and stained with haematoxylin-eosin. The SEC was divided into eight main stages based on meiotic division and morphology as well as on the position of more mature spermatids (Guraya and Bilaspuri, 1976b).

The quantitative aspects of spermatogenesis were investigated by counting the whole nuclei as well as their identifiable portions in the round seminiferous tubules. These counts were made in at least 80 tubules at each stage of the SEC. The minimum number of tubules counted per animal and per testis was 250 and 120, respectively. The counts of the spermatogenetic cells were corrected for differences in nuclear diameter by Abercrombie's formula (Abercrombie, 1946). The arithmetic mean and the standard error were calculated for each cell type. The small portions of the Sertoli cells were not counted.

\section{Results.}

The composition of the various stages and sub-stages was similar to that already reported by Guraya and Bilaspuri (1976b) and is therefore omitted here.

Spermatogonia. - Even the dimensions of the same type of spermatogonia varied at different stages of the cycle (table 1). The dimensions of different types of spermato-

TABLE 1

Variations in spermatogonial nuclear diameter $(\mu)$ and volume $\left(\mu^{3}\right)$ in buffolo

\begin{tabular}{clll}
\hline Spermatogonia & Stages & Diameter & Volume \\
\hline $\mathrm{A}_{0}$ & $1-8$ & 7.95 & 264 \\
$\mathrm{~A}_{1}$ & $3 \mathrm{~b}-4$ & 7.60 & 230 \\
& 6 & 8.41 & 313 \\
& $8-1 \mathrm{a}$ & 9.05 & 390 \\
& $1 \mathrm{~b}$ & 9.45 & 443 \\
$\mathrm{~A}_{2}$ & $2 \mathrm{a}$ & 7.15 & 192 \\
$\mathrm{~A}_{3}$ & $2 \mathrm{~b}$ & 7.48 & 219 \\
$\mathrm{I}_{\mathrm{n}}$ & $3 \mathrm{a}$ & 6.75 & 161 \\
$\mathrm{~B}_{1}$ & $3 \mathrm{~b}$ & 7.24 & 199 \\
$\mathrm{~B}_{2}$ & 7 & 7.01 & 181 \\
& $8 \mathrm{a}-1 \mathrm{a}$ & 6.65 & 154 \\
\hline
\end{tabular}


cytes have already been described by Guraya and Bilaspuri (1976a). The number of round seminiferous tubules found at each stage in which the number of spermatogenetic cells was counted is given in table 2 . An average of 2.5 type-A spermatogonia was present at stage $1 \mathrm{~b}$. That number increased to 4.9 at stage $2 a$ and to 8.9 at stage $3 a$. From table 2, it is clear that the major portion of $A_{1}$ and $A_{2}$-spermatogonia divided at stages $1 c$ and $2 b$, respectively. All type- $A_{1}$ spermatogonia divided to form $A_{2}$-spermatogonia, and therefore $A_{1}$-spermatogonia were absent at stage 2 (fig. 1). Simiarly, all type- $A_{2}$ spermatogonia divided to form type-A spermatogonia of stage 3 which were of two kinds, i. e. $A_{3}$ and $A_{1}$ (fig. 1). In fact, the former were larger in size and contained one or more nucleoli, whereas the latter were small and contained only one nucleolus. $A_{3}$-spermatogonia contained more heterochromatin than $A_{1}$-spermatogonia. The number of $A_{3}$-spermatogonia was almost three times that of $A_{1}$-spermatogonia. This indicated that there might be two different kinds of divisions in $A_{1}$-spermatogonia (fig. 1). In the second type, only $A_{3}$-spermatogonia were formed. So, the division of $A_{2}$-spermatogonia between stages 2 to 3 has been called «equivalent nodal division ».

FIG. 1. - Spermatogonial divisions in buffalo.

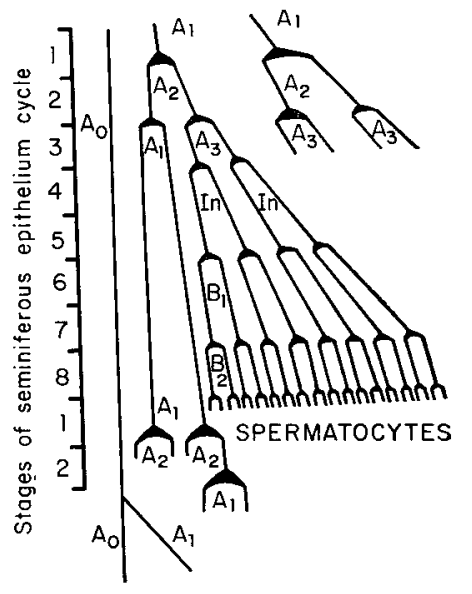

$A_{1}$-spermatogonia showed progressive size increase from stage 3 till the end of the cycle (table 2) ; however, their number decreased from 2.5 to 2.0 (table 2), showing a 20 p. 100 degeneration of type- $A_{1}$ spermatogonia.

The substraction of type-A spermatogonia at stage $4 a$ (type- $A_{1}$ ) from those in stage $3 a$ (type- $A_{1}+A_{3}$ ) indicated that 6.4 type- $A_{3}$ spermatogonia divided in stage $3 \mathrm{~b}$ to produce 10.4 (In) spermatogonia in stage $4 \mathrm{~b}$ (fig. 1). This indicated 18.75 p. 100 degeneration of $\mathrm{A}_{3}$-spermatogonia before their division to form In-spermatogonia. In-spermatogonia were smaller and contained more small-sized nucleoli as compared to $A_{3}$-spermatogonia in stage $3 b$ (table 1 ).

The number of In-spermatogonia remained more or less constant in stages 4 to 5 in which they were present. This suggested that only one generation of In-spermatogonia was formed in one SEC (fig. 1). At the end of stage 5,10.2 In-spermatogonia divided (fig. 1) to form 15.5 B-spermatogonia, showing a 10.2 p. 100 degeneration of In-spermatogonia during division. 


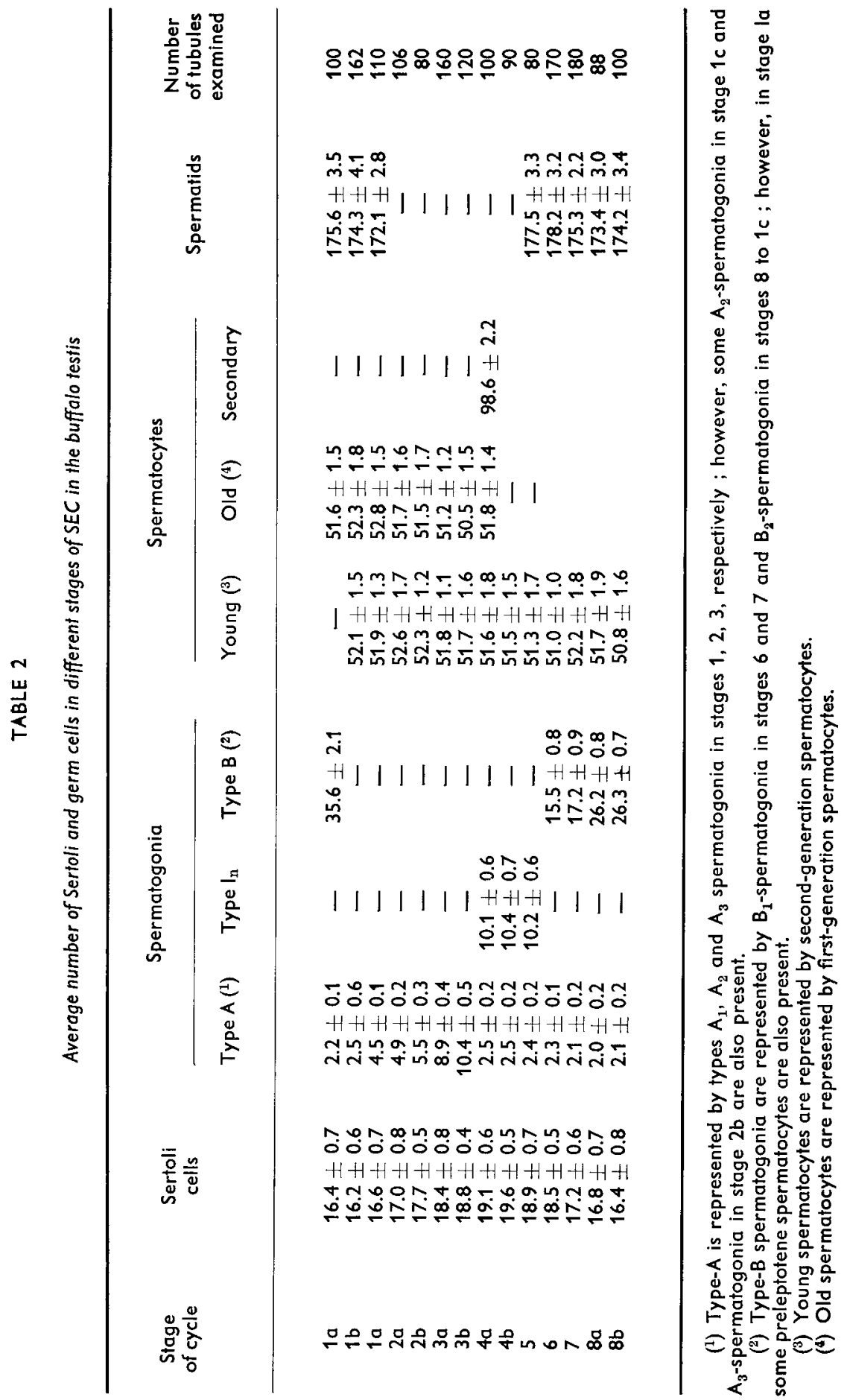


$B_{1}$-spermatogonia were smaller and contained a larger number of smaller nucleoli than In-spermatogonia. Some $B_{1}$-spermatogonia divided at stage 6 to form $B_{2}$-spermatogonia ; however, most of them divided between stages 7 and $8 a$ (fig. 1 ). $15.5 \mathrm{~B}_{1}$-spermatogonia divided to produce $26.2 \quad \mathrm{~B}_{2}$-spermatogonia, showing a 15.5 p. 100 degeneration. The daughter spermatogonia were even smaller and contained more spherical nuclei with a greater number of smaller nucleoli. Except in $A_{2}$ and $B_{2}$-type spermatogonia, which do not show any degeneration, the nuclei in some of the other types of spermatogonia were fragmented, denoting that they were in the process of degeneration. The fragmentation was more pronounced in $A_{1}$-type spermatogonia during stages 5 to $8 a$.

A special type of spermatogonium, called an AO-spermatogonium, was also observed during those stages. Those spermatogonia had a round nucleus with pale, granular chromatin having no karyosomes and one or more small nucleoli. The number of $A_{0}$-spermatogonia remained almost constant throughout the SEC, indicating that they might be dividing only rarely. The number of $A_{1}$-spermatogonia started increasing in stage $8 \mathrm{~b}$ and continued up to stage $1 \mathrm{~b}$. It is suggested that $A_{0}$ spermatogonia may be responsible for that increase by producing more $A_{1}$-spermatogonia at those stages (fig. 1). As the division of $A_{0}$-spermatogonia did not decrease their own number, it would seem that they may divide to produce two types of cells at the same time, those responsible for restoring the number of $A_{1}$-spermatogonia and others ( $A_{0}$-spermatogonia) for maintaining their own number (fig. 1). $A_{0}$-spermatogonia may thus be called reserve stem cells.

Spermatocytes and spermatidis. - $\mathrm{B}_{2}$-spermatogonia divided genelally at the end of stage la or very rarely in stage 8 a to form spermatocytes whose number remained constant through various phases of meiosis at all stages of the SEC. Their number was double that of $B_{2}$-spermatogonia. These observations indicate that $B_{2}$ spermatogonia and primary spermatocytes do not degenerate. In stage $4 a, 98.6$ secondary spermatocytes were produced. This number was almost double that of primary spermatocytes, showing that there was no degeneration of spermatocytes during the first meiosis. However, it was difficult to count the number of secondary spermatocytes. This was due to the fact that the secondary spermatocytes were found associated with spermatocytes in either diplotene or diakineses (stage 4a) or with newly formed spermatids (stage 4b). They were rarely seen in the absence of those cellular associations. To avoid any error, only the tubules containing either secondary spermatocytes alone or those associated with spermatocytes in diplotene or diakinesis (stage 4a) were considered for secondary spermatocyte counting. The number of spermatocytes in diplotene or diakinesis stage was corrected for the nuclear diameter and then doubled to obtain the number of secondary spermatocytes. It was thus assumed that each primary spermatocyte formed two secondary spermatocytes. That supposition overlooked the possibility of primary spermatocyte degeneration during meiosis, which was supported by the absence of any degeneration of the oldest primary spermatocytes in stage $4 a$.

89.6 secondary spermatocytes undergoing meiosis II at stage $4 \mathrm{~b}$ produced 177.5 spermatids at stage 5 . That number was less than double the number of secondary spermatocytes, indicating that while undergoing meiosis II, 10 p. 100 of the secondary 
spermatocytes degenerated. The number of round spermatids during various stages of the SEC apparently was not constant, but their small increase or decrease did not follow any regular trend. This showed that the small variations in the number of round spermatids in different stages may be due to counting errors rather than to their degeneration.

The number of Sertoli cells remained almost constant at different stages of the cycie (table 2). However, their number could not be corrected for differences in nuclear diameter because the shape of their nuclei varied with the stage of the cycle. During the detachment of elongated spermatids from Sertoli cells (stages 6,7) some of the nuclei were spindle-shaped and most of them flattened against the basement membrane. From the release of spermatozoa (8b) till the formation of the next generation of spermatid bundles (stage $2 b-3 a$ ), the nuclei lay along the basement membrane in the form of a triangle. The constant number of Sertoli cells throughout the cycle shows that they do not divide in the mature buffalo testis.

\section{Discussion.}

Six peaks of spermatogonial mitosis have been described in the buffalo (fig. 1). The first three peaks were due to type-A spermatogonia, the fourth to In-spermatogonia and the last two to type-B spermatogonia. In contrast to the present study, five peaks of spermatogonial mitosis have been described after quantitative analysis of spermatogonial behaviour in the ram (Ortavant, 1958) and the bull (Ortavant, 1959 ; Amann, 1962). However, re-examination of the mitotic activity of spermatogonia in the bull, using ${ }^{3} \mathrm{H}$-thymidine labelling techniques, suggested that spermatogonia have six successive mitotic divisions (Hochereau de Reviers, 1970). According to the scheme proposed for spermatogonial renewal in the buffalo, there are three generations of type-A spermatogonia $\left(A_{1}, A_{2}, A_{3}\right)$, one of In-spermatogonia and two of type-B spermatogonia $\left(B_{1}, B_{2}\right)$. Their number varies with the species and the technique used (see Clermont, 1972b). In the buffalo, the same type of nodal division took place among type- $A_{2}$ spermatogonia at stages 2 to 3 to produce new $A_{1}$ spermatogonia in addition to $A_{3}$ spermatogonia, as also suggested for the bull (Hochereau de Reviers, 1970). In contrast to this, the renewal of spermatogonial stem cells by bivalent mitoses of type- $A_{1}$ spermatogonia has been suggested in the ram (Ortavant, 1958) and the bull (Ortavant, 1958).

In buffalo, the bivalent nodal division to form In-spermatogonia occurred at the, end of stage 3 as compared to that found at stage 4 in the bull (Hochereau de Reviers, 1970). In spermatogonia divided between stages 5 and 6 in the buffalo (fig. 1) as compared to their division at stage 5 in the bull (Hochereau de Riviers, 1970). $B_{1}$-spermatogonia divided between stages 7 and 8 to form $B_{2}$-spermatogonia. One type of $A_{0}$ spermatogonia was present throughout the SEC and divided slowly and sporadically to give rise to a new type of $A_{0}$ and type- $A_{1}$ spermatogonia. Based on the classification of Leblond et al. (1967), the mode of spermatogonial renewal in the buffalo may be determined by the different types of spermatogonia classified into three categories ; reserve stem cells $\left(A_{0}\right)$, renewing stem cells $\left(A_{1}, A_{2}\right)$ and differentiating cells $\left(A_{3}\right)$. This mode of spermatogonial renewal resembles that in the bull (Hochereau de Reviers, 1970). 
Specific cell degeneration at various stages of spermatogenesis has also been reported in other mammals (Courot ef al., 1970 ; Clermont, $1972 b$; Berndtson and Desjardins, 1974). In the buffalo, most degeneration takes place during spermatogonial mitoses. The extent of degeneration at the various stages of sperm formation can be well judged by the mean number of spermatids produced per $A_{3}$ spermatogonium available for division after stage $3 \mathrm{~b}$. That number was $43.32 \mathrm{p} .100$ of the number corrected in the absence of degeneration and was similar to observations in the bull (43 p. 100) (Berndtson and Desjardins, 1974). Similar to the present observations, no degeneration was reported throughout long meiotic prophase in the primary spermatocytes of the mouse (Oakberg, 1955) or the bull (Amann, 1962 ; Berndtson and Desjardins, 1974).

Although there was no degeneration during the formation of secondary spermatocytes in the buffalo, it has been reported in the bull (Berndtson and Desjardins, 1974) and observed by Ortavant (1956) and Attal and Courot (1963). Amann (1962) and Swierstra (1966) found little germ cell degeneration after the first or second reduction division. In comparison to other spermatogenetic cells, $A_{2}$ and $B_{2}$-type spermatogonia, primary spermatocytes and spermatids did not show any degeneration. The resistance of these cells cannot be explained. Future studies on the cause of degeneration, hormonal control of spermatogenesis and the differential metabolism of various spermatogenetic cells will definitely help us to determine the reason for their resistance.

After stage 1c, the number of spermatids could not be counted because they were unevenly distributed and starting to elongate. However, some spermatids may degenerate between stages $2 a$ to 8 , as during that time, chromatin condensation and other conspicuous changes occur. The loss of similar cells has been reported in other species (Clermont, 1972b).

One $A_{3}$ spermatogonium, available for division after stage $3 b$, produced 27.73 p. 100 of the spermatozoa in the buffalo, which is almost the same as reported in the bull (Berndtson and Desjardins, 1974), whereas the expected number was 64 . Future studies will reveal the loss of spermatozoa during transport through the epididymis and the vas deferens. From this discussion, it can be concluded that a significant portion of spermatogenetic cells in various stages of development and differentiation is lost through the degenerative process, thereby affecting the efficiency of spermatogenesis.

Variations in the shape and size of the Sertoli cell nucleus found in the buffalo testis have been reported in other species (see Courot ef al., 1970 ; Berndtson and desjardins, 1974). Similar to the condition in the buffalo, the Sertoli cells do not divide in the adults of other mammalian species and therefore their number remains constant (Attal and Courot, 1963 ; Berndtson and Desjardins, 1974 ; Guraya, 1980).

Reçu en septembre 1979. Accepté en janvier 1980.

Résumé. Le comportement qualitatif des cellules de la lignée spermatogénétique et des cellules de Sertoli chez le buffle (Bubalus bubalis) a été étudié en identifiant les 8 stades du cycle de l'épithélium séminifère, basés sur les divisions méïotiques, la morphologie ef la position des spermatides les plus âgées. Pour obtenir de meilleurs résultats, on a subdivisé 
les stades $1,2,3,4$ et 8 . Six pics de mitoses spermatogoniales suggèrent l'existence de six générations de spermatogonies, parmi lesquelles trois proviendraient des spermatogonies $A\left(A_{1}, A_{2}, A_{3}\right)$, deux des $B\left(B_{1}, B_{2}\right)$ et une des intermédicires. Cependant, une autre catégorie de spermatogonies, $A_{0}$, qui se divisent rarement, est également présente à tous les stades du cycle. Les spermatogonies $A_{1}, A_{3}$, intermédiaires, $B_{1}$ ef les spermatocytes secondaires présentent respectivement un taux de dégénérescence de $20,18,75,10,2,15,5$ ef 10 p. 100 . Nous n'avons pas observé de dégénérescence parmi les spermatogonies $A_{2}$ et $B_{2}$, les spermatocytes primaires ou les spermatides. La dégénérescence d'une partie des cellules de la lignée spermatogénétique affecte le rendement de la spermatogenèse.

\section{Références}

ABERCROMBIE M., 1946. Estimation of nuclear population from microtome sections. Anat. Rec., 94, 238-248.

AMANN R. P., 1962. Reproductive capacity of daily bulls. IV. Spermatogenesis and testicular germ cell degeneration. Am, J. Anat., 110, 69-78.

ATTAL J., COUROT M., 1963. Développement testiculaire et établissement de la spermatogenèse chez le taureau. Ann. Biol. anim. Biochim. Biophys., 3, 219-241.

BERNDTSON W. E., DESJARDINS C., 1974. The cycle of seminiferous epithelium and spermatogenesis in the bovine testis. Am. J. Anat., 140, 167-180.

CLERMONT Y., 1972a. Quantitative analysis of spermatogenesis of the rat : A revised model for the renewal of spermatogonia. Am. J. Anat., 111, 111-129.

CLERMONT Y., 1972b. Kinetics of spermatogenesis in mammals : Seminiferous epithelium cycle and spermatogonial renewal. Physiol. Rev., 52, 198-236.

COUROT M., 1962. Développement du testicule chez l'agneau. Ełablissement de la spermatogenèse. Ann. Biol. anim. Bioch. Biophys., 2, 25-41.

COUROT M., HOCHEREAU-DE-REVIERS M. T., ORTAVANT R., 1970. Spermatogenesis. In A. D. JOHNSON, W. R. GOMES, N. L. VAN DEMARK. The Testis, vol. 1, 339-432. Acad. Press, New York.

DESCLIN J., ORTAVANT R., 1963. Influence des hormones gonadotropes sur la durée des processus spermatogénétiques chez le rat. Ann. Biol. anim. Bioch. Biophys., 3, 329-342.

GURAYA S. S., 1980. Recent progress in the morphology, histochemistry, biochemistry, and physiology of developing and maturing mammalian testis. Int. Rev. Cytol., 62, 187-309.

GURAYA S. S., BILASPURI G. S., 1976a. Spermatogenic cells of the buffalo (Bubalus bubalis) festis. Ind. J. Anim. Sci., 46, 388-395.

GURAYA S. S., BILASPURI G. S., 1976b. Stages of seminiferous epithelial cycle and relative duration of spermatogenic processes in the buffalo (Bos bubalis). Morph. J., 122, 147-161.

GURAYA S. S., BILASPURI G. S., 1976c. Stages of seminiferous epithelial cycle in the buffalo (Bos bubalis). Ann. Biol. anim. Bioch. Biophys. 16, 137-144.

HOCHEREAU-DE-REVIERS M. T., 1970. Efudes des divisions spermatogoniales et du renouvellement de la spermotogonie-souche chez le taureau. D. Sc. Thes., Fac. Sci., Paris.

LEBLOND C. P., CLERMONT Y., NADLER N. J., 1967. The pattern of stem cell renewal in three epithelia (oesophagus, intestine and testis) Proc. can. Cancer Res. Conf., 7, 3-30.

OAKBERG E. F., 1955. Sensitivity and time of degeneration of spermatogenetic cells irradiated in various stages of maturation in the mouse. Rad. Res., 2, 369-391.

ORTAVANT R., 1958. Le cycle spermatogénétique chez le bélier. D. Sc. Thes., Fac. Sci., Paris.

ORTAVANT R., 1959. Spermatogenesis and morphology of the spermatozoon. In H. H. COLE, P. T. CUPPS, Reproduction in domestic animals 1st ed. Vol. II, 251-276. Acad. Press, New York.

SWIERSTRA E. E., 1966. Structural composition of short horn bull testes and daily spermatozoa production as determined by quantitative testicular histology. Can. J. Anim. Sci., 46, 107-119. 